DOI: https://doi.org/10.32839/2304-5809/2021-3-91-77

УДК [336.773:339.564]:33.06](477)

Ксензук О.С., Підхомний О.М.

Львівський національний університет імені Івана Франка

\title{
МОЖЛИВОСТІ ЕСА-ФІНАНСУВАННЯ В УКРАЇНІ ТА ЙОГО ВПЛИВ НА ЕКОЛОГІЮ
}

Анотація. У статті досліджено такий інноваційний фрінансовий інструмент, як ЕСА-фрінансування фінансування підприемств за підтримки експортно-кредитних організацій. Висвітлено основні переваги і недоліки використання даного фінансового інструменту іноземними підприемствами. Описано ризики, які покриває та одночасно може викликати дана схема фінансування. Вказано про доцільність залучення українськими підприемствами ЕСА-фрінансування при формуванні капіталу як перспективної та вигідної форми фінансування. Визначено чинники, які можуть стати перешкодами у поширенні цього фінансового інструмента в Україні. Зроблено висновок про різні аспекти ЕСА-фрінансування, такі як вартість залучених коштів та вплив проєктів, що фрінансуються, на екологічну ситуацію

Ключові слова: ЕСА-фрінансування, Експортні кредитні агентства, інвестиційне проектне фінансування, фрінансова звітність, екологічні наслідки, ризики.

Ksenzuk Olena, Pidkhomnyy Oleg Ivan Franko National University of Lviv

\section{ECA-FUNDING OPPORTUNITIES IN UKRAINE AND ITS IMPACT ON THE ENVIRONMENT}

Summary. The article examines such an innovative financial instrument as ECA-financing - financing of enterprises with the support of export credit organizations. Are specified the main advantages of raising funds are a rate lower than the interest rate of a bank loan, favorable amortization period, the possibility of deferring the payment of the principal amount of debt and accrual of interest at least until the commissioning of the investment object, and the main disadvantages are that debt users in modern conditions face the risk of default, support for export credit organizations projects that adversely affect the environment) of using of this financial instrument by foreign companies. Are specified the covered risks (compliance, insolvency of the buyer, non-fulfillment of payment obligations) and at the same time can be caused (environmental, cultural, social) by this scheme of financing. Are described the expediency of attracting ECA-financing by Ukrainian enterprises in the formation of capital as a promising and profitable form of financing, which has a competitive advantage over a bank loan. The financing conditions provided by banks in Ukraine as of today are considered. Factors that may become obstacles to the spread of this financial instrument in Ukraine are identified. The probable consequences of the impact of the crisis caused by the pandemic in 2021 and beyond are highlighted. Prospects of ECA-financing in the world, possible transformation of the largest in volume (coal and nuclear energy, defense) directions of financing and termination of financing of the spheres which projects have influence on climate changes are considered. Various aspects of ECA funding, such as the cost of borrowing, the impact of funded projects on the environmental situation, the risk of default due to the pandemic crisis; the need to make an advance payment; requirements for the preparation of financial statements and the minimum amount of the contract for financing are concluded.

Keywords: ECA-financing, Export credit agencies, investment project financing, financial reporting, environmental consequences, risks.

Постановка проблеми. Глобалізаційні процеси, які відбуваються у сучасних умовах, визначають значення інвестицій для розвитку світового господарства та економіки України зокрема. Інвестиційні ресурси в умовах фрінансової глобалізації переважно є заученими. Це зумовлюе необхідність використання та диференціації боргових фрінансових інструментів.

Для розвитку економіки України важливим $\epsilon$ едективне здійснення інвестиційної діяльності. Використання інноваційних глобальних dpiнансових інструментів дасть змогу підвищити інвестиційну активність вітчизняних підприємств.

Ринкові форми фрінансування бізнесу в Україні перебувають на етапі початкового формування. Тому варто досліджувати можливості впровадження фрінансових інструментів, які поширені у практиці країн з високим рівнем економіки та є новими для економіки України.

Важливо враховувати екологічні наслідки проєктів, що фрінансуються, на клімат та навко- лишне середовище у довгостроковій перспективі.

Аналіз останніх досліджень і публікацій. Дослідження засад фрінансування діяльності підприємств описані у працях закордонних економістів Маршала А., Ламберта Т. та ін. Традиційні та інноваційні інструменти кредитного ринку досліджували такі науковці, як О.А. Островська [1], О.В. Булавинець, О.В. Романишин [2], Т.В. Майорова [3; 4] та ін. Проблемам фрінансового забезпечення інноваційного розвитку України присвячені праці В.М. Опаріна, T.В. Майорової, М.І. Диби [5], О.М. Юркевич, I.А. Павленко [6] та ін.

Виділення не вирішених раніше частин загальної проблеми. 3 проблемою фінансування зіштовхуеться багато підприемств у сучасному світі. Щоб залишатись конкурентоспроможними, всі підприемства повинні залучати кошти. Специфріка важкої промисловості полягає у тому, що часто необхідне додаткове фрінансування 3-за кордону. Оскільки в Україні підприємства не мо- 
жуть брати кредитів в іноземній валюті, якщо не мають виторгу в іноземній валюті, фрінансування експортних організацій дасть змогу вітчизняним підприемствам отримувати кошти на кращих умовах. Крім нижчої вартості, у деяких випадках таке фінансування передбачає технічну підтримку з боку позичальника. Також у сучасних умовах дедалі більш важливим стає екологічний вплив проектів.

Метою статті є дослідження доцільності використання при формуванні капіталу суб'єктів господарювання У країни такого фрінансового методу як ECA-фрінансування та головних переваг і недоліків використання даного фрінансового інструменту та його впливу на екологію.

Виклад основного матеріалу. У досвіді розвинених країн світу значну роль відіграють спеціалізовані фрінансові установи у формі експортних кредитних агентств.

Експортні кредитні агентства та агентства страхування інвестицій, широко відомі як ECA, $є$ державними установами, які надають державні позики, гарантії, кредити та страхування приватним корпораціям. Вони полегшують цим корпораціям ведення бізнесу за кордоном, особливо у фінансово та політично ризикованому світі, що розвивається. Підтримка експортних кредитів є важливим джерелом фонансової підтримки транскордонної торгівлі [7].

У більшості випадків ЕСА беруть безпосередню й активну участь у забезпеченні виконання державної фрункщії зі стимулювання та сприяння збільшенню обсягів експортних постачань високотехнологічної продукції з високим рівнем доданої вартості [9].

Їх мета - сприяти експорту з власної країни 3 кінцевою метою підтримати рівень зайнятості та економіку своєї країни [7].

ECA в сукупності є одними з найбільших джерел державної фрінансової підтримки участі іноземних корпорацій у промислових проектах, які втілюють у країнах, що розвиваються.

Основними перевагами ЕСА-фрінансування є залучення коштів за ставкою нижчою, ніж відсоток банківського кредиту, вигідний термін амортизації, а також можливість надання відтермінування виплати основної суми боргу та нарахування відсотків, щонайменше, до моменту введення в експлуатацію інвестиційного об’єкта (до двох років).

Такий тип фрінансування може зацікавити підприемства, які здійснюють масштабні закупівлі машин і обладнання за кордоном в рамках власних інвестиційних програм. Загалом підтримка проектів поширена у проектному фрінансуванні, авіащійному фінансуванні та фінансуванні судноплавства.

На сьогодні в Україні ЕСА-фрінансування надають «ОТП Банк Україна» та «Укрексімбанк». В «ОТП Банк Україна" Мінімальною сумою фінансування є 1 мільйон доларів США або еквівалент в інших валютах. Фінансування надається на 3-5 років у форомі строкового кредиту. Авансовий платіж повинен становити не менше 15\% від вартості техніки/промислового обладнання. Пільговий період погашення тіла кредиту: до дати постачання/введення в експлуатацію імпортованого обладнання. Погашення кредиту здійснюеться рівними щоквартальними чи піврічними частками. Валютою фінансування є долари США або евро [8].

Можливе забезпечення (або його комбінація):

- застава основних засобів (цілісних майнових комплексів, нерухомого майна, обладнання, транспортних засобів, сільськогосподарської техніки);

- застава товарно-матеріальних цінностей в обороті;

- застава майнових прав вимоги за договорами банківського вкладу, розміщеного в ОТП Банку;

- банківська гарантія повернення кредиту;

- корпоративна гарантія компанії, прийнятної для банку, або фрінансове поручительство власників бізнесу [6].

За першими проектами у рамках цієї угоди банк планує надавати українським експортерам фінансування оборотного капіталу на суму до 5 мільйонів гривень та на строк до 2 років для виробництва продукції та реалізації робіт і послуг експортного призначення. Перевагами для експортера мають стати прискорена процедура прийняття рішення та зменшення вимог щодо забезпечення, яким в тому числі може виступати страхове покриття ЕСА на суму до $85 \%$ кредиту або ліміту [14].

Види підтримки, які пропонують ЕCA:

- Пряме фінансування.

- Гарантії.

- Страхування [10].

Надання підтримки через пряме фрінансування та гарантії передбачає прийняття з боку ECA комплаенс-ризику. При прямому фінансуванні ECA бере участь у підготовці документів. При наданні підтримки у формі гарантії ЕCA можуть не брати участі у підготовці документів, проте беруть участь у переговорах щодо укладення договорів між кредитором, що підтримується ЕСА, та закордонним покупцем, що є позичальником. Агентства не беруть на себе ризик документації при страхуванні, тому що участь у підготовці документів бере банк, який повинен забезпечити дотримання умов страхування.

Також ЕСА страхує ризики безпідставної відмови сплатити рахунок, неплатоспроможності або банкрутства іноземного покупця, а також політичні ризики, ризики невиконання платіжних зобов'язань, спричинених стихійними лихами, промисловими аваріями, запровадженням мораторію на здійснення платежів у країні імпортера, застосуванням ембарго на торгівлю та іншими та ін. [15]. Вищі шанси на отримання фрінансування у підприемств із прозорою фінансовою звітністю, історією купівель в іноземних компаній та позитивною статистикою виплат.

Для отримання фінансування фрінансова звітність за 2 останні роки повинна бути складена за Міжнародними стандартами фрінансової звітності.

Серед недоліків ЕСА-фрінансування можна виокремити те, що користувачі боргу у сучасних умовах стикаються 3 ризиком дефолту. Певні галузі - зокрема транспорт та нафрто- і газовидобувна промисловості - зазнали серйозних негативних наслідків через відсутність доходів у зв'язку з пандемією COVID-19. Оскільки криза, спричинена пандемією, продовжуватиметься у 2021 році й надалі, із закінченнями термінів 
договору до позичальників з'являться претензіі щодо погашення заборгованості. Кредитоспроможність частини користувачів фрінансування послаблюється та експерти вважають, що виникнення претензій є питанням часу. Для користувачів, де потреба фрінансування ключових індраструктурних об'єктів є критичною, вплив кризи буде відчутним протягом тривалого часу [11].

Ще одним недоліком є те, що ЕCA підтримує вдвічі більше нафртових, газових та гірничих проектів, ніж усі банки розвитку (Multilateral development banks), такі як Група Світового банку. Половина всіх нових промислових проектів, що викидають парникові гази, у країнах, що розвиваються, має певну форму підтримки ECA. ECA часто підтримують такі проекти, хоча Група Світового банку та інші банки розвитку вважають їх занадто ризикованими та потенційно шкідливими для підтримки [12].

За останні роки ECA щорічно надавали підтримку від 50 до 70 млрд доларів США в рамках так званих "середньо- та довгострокових операцій", значна частина яких - великі промислові та інфрраструктурні проекти в країнах, що розвиваються. Багато 3 цих проектів мають дуже серйозні екологічні та соціальні наслідки.

Оскільки значна частина із цих проектів мають високий ризик через їх екологічний, політичний, соціальний та культурний вплив, більшість із них не змогли б реалізуватись без фінансової підтримки ЕСА. Зважаючи на те, що у світі зростає підтримка саме «зелених» проектів, за даними Export Finance Industry Report, за 2020 рік майбутне фінансування промислового виробництва буде «зеленим». Керовані почуттям морального обов'язку разом із банками, ЕСА стають більш зацікавленими у проектах, які $е$ нешкідливими для суспільства та навколишнього середовища. Вугільна, ядерна енергетика та оборона - це перші галузі, з якими ЕСА можуть припинити співпрацю через негативний вплив на навколишнє середовище [13].

За даними Fossil Fuel Finance Report 2021, за останні 5 років фінансування викопного палива становило 3,8 млрд доларів [15]. Незважаючи на те, що загальне фінансування викопного палива скоротилось в 2020 році, фрінансування з січня по червень було найвищим за останні 5 років - майже 500 тис доларів, оскільки великі енергетичні компанії збільшували залучення дешевих боргових коштів на початку глобальної пандемії. Отже, експортним кредитним організаціям слід зосередитись на трансформації фрінансування проектів, що мають негативний вплив на екологію.

Висновки і пропозиції. За результатами проведених досліджень можна зробити певні висновки.

ECA-фрінансування має шанси щодо поширення в Україні. Використання нової форми фрінансування бізнесу має як переваги, так і недоліки. Серед основних переваг можна виділити покриття комерційного, політичного ризиків та ризику документації; меншу вартість у порівнянні із банківським кредитом; наявність пільгового періоду погашення. Недоліками ЕCA-фрінансування $є$ ризик непогашення зобов'язань у зв'язку з кризою спричиненою пандемією; необхідність внесення авансового платежу; вимоги щодо складання фрінансової звітності та мінімального обсягу контракту для фінансування.

Отже, перешкодою можуть стати жорсткі початкові умови фінансування, а також відсутність чітких норм правового регулювання у зв'язку з браком досвіду використання.

Передумовою для розвитку та поширення використання ECA-фрінансування в Україні е спрощення фрінансової звітності та перехід на Міжнародні стандарти; спрощення документообігу загалом; внаслідок цього зменшення часу та вартості трансакційних витрат для укладання угод

ECA-фрінансування має вигідні цінові умови, проте також впливає на стан навколишнього середовища, залежно від проектів. Світ дедалі більше рухається до зменшення негативного впливу від промисловості, і Україні необхідно також прагнути до впровадження проєктів, нешкідливих для екології у довгостроковому періоді. За оцінками експертів, необхідно відповідально ставитись до обов'язків щодо стану екології та припиняти забруднення клімату, щоб уникнути катастрофрічних наслідків.

Тому питання щодо переваги позитивних чи негативних наслідків ЕСА-фрінансування залишається відкритим і потребує подальших досліджень.

\section{Список літератури:}

1. Островська О. А. Нові форми фрінансування бізнесу в Україні Фінанси, облік $і$ аудит. 2017. № 1. С. $174-187$.

2. Романишин О. В. Інноваційні інструменти кредитного ринку як джерело формування позиченого капіталу підприемств в Україні. Інвестицї: практика та досвід. 2015. № 15. С. 51-55.

3. Майорова Т. В. Проектне фінансування. КНЕУ : підручник / за заг. ред. Т. В. Майорової. Київ, 2017.434 с.

4. Майорова Т. В. Інвестиційний податковий кредит як непрямий метод фінансування інноваційної діяльності. Еконоліка та держава. 2015. № 2. С. 31-34.

5. Диба М. І. Концесія: сутність та форми фрінансового забезпечення. Фінанси України. 2016. № 10. С. $65-76$.

6. Інноваційне підприемництво у трансформаційній економіці України. КHEУ: монографія. Київ, 2007.248 с.

7. Trade finance: Export Credit Agency finance - overview LexisAsk. URL: https://www.lexisnexis.com/uk/lexispsl/ bankingandfinance/document/391289/55KB-65S1-F185-X0NV-00000-00/Trade_finance_Export_Credit_Agency_ finance_overview (дата звернення: 25.03.2021).

8. Фінансування імпорту за участі Експортних кредитних агентств (Financing of Import with participation of ECA). URL: https://www.otpbank.com.ua/big-corporate/products-financing/main-structured/eca/ (дата звернення: 26.03.2021).

9. Особливості запровадження експортно-кредитного агентства в Україні. URL: https://feao.org.ua/wp-content/ uploads/2019/01/eca_ukraine.pdf (дата звернення: 26.03.2021).

10. Damian McNair. Export credit financing. URL: https://www.pwc.com.au/legal/assets/investing-in-infrastructure/ iif-29-export-credit-financing-feb16-3.pdf (дата звернення: 26.03.2021).

11. Max Thompson. Export finance: 2020 year-end review. URL: https://www.txfnews.com/News/Article/7104/Exportfinance-2020-year-end-review (дата звернення: 26.03.2021). 
12. What are ECAs? URL: https://www.eca-watch.org/node/1\# (дата звернення: 24.03.2021).

13. Dr Tom Parkman. Export Finance Industry Report 2020. URL: https://www.txfnews.com/Image/ DownloadFile?FileName=Export_Finance_Industry_Report_2020_compressed.pdf (дата звернення: 24.03.2021).

14. Укрексімбанк та Експортно-кредитне агентство. URL: https://www.eximb.com/ua/bank/press/novyny-banku/ ukreksimbank-ta-eksportno-kredytne-agentstvo-rozpochaly-spivrobitnyctvo.html (дата звернення: 26.03.2021).

15. EКА почало страхувати вітчизняних експортерів. URL: http://www.ooru.org.ua/news/394.eka-pochalostrakhuvati-vitchiznyanikh-eksporteriv.htm (дата звернення: 24.03.2021).

16. FOSSIL FUEL FINANCE REPORT 2021 URL: http://priceofoil.org/content/uploads/2021/03/Banking_on_ Climate_Chaos_2021.pdf (дата звернення: 24.03.2021).

\section{References:}

1. Ostrovska O. A. (2017) Novi formy finansuvannya biznesu v Ukrayini [New forms of business financing in Ukraine]. Finansy, oblik $i$ audyt, no. 1, pp. 174-187. (in Ukrainian)

2. Romanyshyn O. V. (2015) Innovacijni instrumenty kredytnogo rynku yak dzherelo formuvannya pozychenogo kapitalu pidpryyemstv $\mathrm{v}$ Ukrayini [Innovative instruments of the credit market as a source of formation of borrowed capital of enterprises in Ukraine]. Investyciyi: praktyka ta dosvid, no. 15, pp. 51-55. (in Ukrainian)

3. Majorova T. V. (2017) Proektne finansuvannya [Project financing]. KNEU: pidruchnyk/za zag. red. T. V. Majorovoyi. Kyiv, 434 p. (in Ukrainian)

4. Majorova T. V. (2015) Investycijnyj podatkovyj kredyt yak nepryamyj metod finansuvannya innovacijnoyi diyalnosti [Investment tax credit as an indirect method of financing innovation]. Ekonomika ta derzhava, no. 2, pp. 31-34. (in Ukrainian)

5. Dyba M. I. (2016) Koncesiya: sutnist ta formy finansovogo zabezpechennya [Concession: the essence and forms of financial security]. Finansy Ukrayiny, no. 10, pp. 65-76. (in Ukrainian)

6. Innovacijne pidpryyemnycztvo u transformacijnij ekonomici Ukrayiny (2007) [Innovative Entrepreneurship in the Transformational Economy of Ukraine]. KNEU: monografiya. Kyiv, 248 p. (in Ukrainian)

7. Trade finance: Export Credit Agency finance - overview LexisAsk. Available at: https://www.lexisnexis.com/uk/ lexispsl/bankingandfinance/document/391289/55KB-65S1-F185-X0NV-00000-00/Trade_finance_Export_Credit_ Agency_finance_overview (accessed 25 March 2021).

8. Finansuvannya importu za uchasti Eksportnyx kredytnyx agentstv (Financing of Import with participation of ECA). Available at: https://www.otpbank.com.ua/big-corporate/products-financing/main-structured/eca/ (accessed 26 March 2021). (in Ukrainian)

9. Osoblyvosti zaprovadzhennya eksportno-kredytnogo agentstva v Ukrayini [Features of the introduction of an export credit agency in Ukraine]. Available at: https://feao.org.ua/wp-content/uploads/2019/01/eca_ukraine.pdf (accessed 26 March 2021).

10. Damian McNair. Export credit financing. Available at: https://www.pwc.com.au/legal/assets/investing-ininfrastructure/iif-29-export-credit-financing-feb16-3.pdf (accessed 26 March 2021).

11. Max Thompson. Export finance: 2020 year-end review. Available at: https://www.txfnews.com/News/Article/7104/ Export-finance-2020-year-end-review (accessed 26 March 2021).

12. What are ECAs? URL: https://www.eca-watch.org/node/1\# (accessed 24 March 2021).

13. Dr Tom Parkman. Export Finance Industry Report 2020. Available at: https://www.txfnews.com/Image/ DownloadFile?FileName=Export_Finance_Industry_Report_2020_compressed.pdf (accessed 24 March 2021).

14. Ukreksimbank ta Eksportno-kredytne agentstvo [Ukreximbank and Export Credit Agency]. Available at: https://www.eximb.com/ua/bank/press/novyny-banku/ukreksimbank-ta-eksportno-kredytne-agentstvorozpochaly-spivrobitnyctvo.html (accessed 26 March 2021). (in Ukrainian)

15. EKA pochalo straxuvaty vitchyznyanyx eksporteriv [ESA began to insure domestic exporters]. Available at: http://www.ooru.org.ua/news/394.eka-pochalo-strakhuvati-vitchiznyanikh-eksporteriv.htm (accessed 24 March 2021). (in Ukrainian)

16. FOSSIL FUEL FINANCE REPORT 2021. Available at: http://priceofoil.org/content/uploads/2021/03/Banking on_Climate_Chaos_2021.pdf (accessed 24 March 2021). 